\title{
Child Labour and Its Determinants in Informal Sector of Onitsha, Anambra State, Nigeria.
}

\author{
Joan N. Ozoh ${ }^{1 *}$, Uzonwanne Maria Chinecherem ${ }^{2,1}$ \\ ${ }^{1}$ Department of Economics, Nnamdi Azikiwe University, Awka, Anambra state \\ *E-mail of Corresponding author : joanozoh@yahoo.com
}

\begin{abstract}
Child labour is a problem that affects children and the society all over the world. Children looses their youth and chance of studying, dangers their health and their future thereby providing harm to the society. This study examined child labour and its determinants in Nigeria with specific focus on informal sector of Onitsha Metropolis, Anambra state. It is a descriptive survey research. Interview schedule was used as instrument for data collection. Non-probability sampling was employed in which the sample were drawn using quota and purposive sampling technique. Data collected were analyzed using descriptive statistics(frequencies, percentages and charts). The aim of this study is to find out what determines the labour supply decisions in onitsha metropolis and also to find out the major causative factors of child labour in Onitsha metropolis. The study finds that parents determines the labour supply decisions in the study area. The findings of this study also showed that factors such as illiteracy, Parents ignorance, low level of awareness, high cost of living and low income also contribute to child labour in the study area. The study recommended amongst others that Anti-child labour watch group should be formed to prosecute and penalize parents who engage their children into labour in Onitsha and also government should provide financial assistance to parents to increase their income.
\end{abstract}

Keywords- Child labour, determinants, informal sector, Onitsha.

\section{Introduction:}

Child labour is a widespread problem in the contemporary world, especially in the developing countries and in urban areas which onitsha is one of them. Child labour involves works that are harmful to a child's health. These works include any work that violates children's fundamental human rights and any work that is dangerous or life- threatening to the child; it also includes works that exhaust children's strength and damage their bodies, works that prevent children from going to school to gain basic skills and knowledge for their future development. With this, child labour is a challenge that every modern society has to contend with. (UNICEF, 2008). Child labour has devastating effects on children, their families, communities in which they live, and generally on national development. The consequences of child labour on child development are obvious. They include health hazard, physical abuse, fatigue, poor school performance, academic wastage, sexual abuse, accident, youth violence among others. Physical and health consequences of child labour include stunting, breathing problems owing to exposure to toxic substances, accident proneness, contamination of cuts and wounds. While cognitive problems include not attending schools, class retention and high dropout rate and achievement deficits. Social and physiological consequences include isolation of working children from their families and peer-groups, stigmatization of work by peers, lowering of self-esteem of children and perception of relative deprivation (1LO, 2002 ).

In Nigeria, there is an upsurge in the incidence of child labourers in the past two decades, making it a full blown industry, especially in the urban areas. This is largely attributed to the economic situation of the country, which has led to the involvement of the children as substantial contributors to their family's income by working as carriers in market places, street hawkers, workshop apprentices, domestic servants, motor park touts, and bus conductors in the urban centers ( Tade, 2010; Taiwo, 2010). Over 4 million children in Nigeria are engaged in economic or labour activities, working long hours in poor and unhealthy conditions and they receive a token fee less than one-third of legislated minimum wage (Oloko, 2004). Over the years, the use of children for labour outside the home has continued to change in form and character in Nigeria (Okpukpara and Odurukwe, 2003).

On daily basis, desperate impoverished Nigerian parents are forced to adopt various clandestine measures to keep their families afloat in the absence of any social safety net. The deplorable situations of most families in 
Nigeria have pushed the children out of their own homes to work in urban centers to earn money to assist their families, with little or no prospect of them acquiring their formal education, which would have broken the cycle of poverty, inherited from their parents (Isamah and Okunola, 2002 ).

Basu (1998), however, views child labour as a way out of poverty especially for poor households. Basu observes that children contribute as much as one-third of household income in poor families. He states that such income could not be treated as insignificant in poverty reduction in poor households. Basu (1998) maintained that the decision to send a child to work is partly matters of social norm. This is stated that if a parent lives in a society where everybody send their children to work, it is worthwhile for each parent to send his child to work and if everybody does not send their children to work each parent may find it not worthwhile

In Anambra State, the crux of the matter at the commemoration of the 2017 Day of African child at the headquarters of the Anambra Broadcasting Service in Awka was the decision of the state government to raid child hawkers who roam the streets and motor parks selling their wares during school hours .Government noted that children of school age who were sent out by their parents and guardians to hawk ended up becoming social misfits and deviants thereby becoming a threat to society.( Ozoji, 2017)

In Onitsha, we notice a daily rise in the number of children who litter the streets in search for a living. Children contribute as much as two-third of household income and their income source cannot be treated as insignificant by poor families. Because of this, some parents decide to have children on the basis of a cost-benefit perspective. They tend to be of economic value and, as a result, become a desirable asset for struggling parents. When the family cannot afford the bare basics of substance, the children in need begin to engage in labour. They make their children bread winners at very tender age while they feed fat on the sweat of these children.

A lot of empirical studies have been carried out on this subject. There is scarcity of the study in Anambra state and no evidence has been given from Onitsha metropolis. Also, while it remains most appealing to attribute the persistence of child labour in Nigeria to poverty (as has been done in most literature), there is need to call to mind and verify other possible determining factors that contribute to child labour in the study area. This is because government's efforts at combating poverty have not reduced child labour significantly. The researcher fills this gap by finding other factors that contribute to child labour in the study area and who determines the child labour supply in the study area. To this end, this paper is organized as follows: section 2 discusses the review of relevant literature, section 3 contains the methods and procedure and section 4 captures the data analysis and discussion while section 5 concludes the study.

\section{Literature Review}

\subsection{Factors Responsible For Child Labour Practices}

Child labour covers the work which children under the age of 18 engage in with the aim of earning a livelihood for themselves or for their families. However, there are many factors that influence child labour in our society. (Basu, 1999) finds the causes of child labour to include parental influence, family size, and lack of labour restrictions, poverty, traditional factors, rapid rural-urban migration, level of education. Among these, poverty is the most expected but nonetheless contentious determinants of child labour. Many factors determine the decision concerning sending child (ren) to school or to work. Adudu (1987) identified five factors such as housing problems, illiteracy, unemployment/underdevelopment, low incomes, and inability to cope with the needs of members of households, as indicators of the extent of poverty among women and consequently child labour. Basu (1998) maintained that the decision to send a child to work is partly matters of social norm. To buttress this fact, he pointed out that if a parent lives in a society where everybody send their children to work, it is worthwhile for parents to send their children to work and if everybody does not send their children to work, each parent may not find it worthwhile. Some societies especially in Africa tend to hold this frame. According to Grootaert (1995), these factors are cost of schooling, characteristics of the child, parents, households and community. These factors exercises influence over the decision to allocate children's time away from schooling or towards work. Other factors include the location and distance to formal education Centre. Specifically, poverty and illiteracy reinforced by traditional customs such as polygamy and preference for large family size were identified as root causes of child labour in Nigeria (Obikeze, 1986). Moreover, marital instability and 
family disorganization were also identified as contributory factors. Be that as it may, the first econometric study of National Child Labour Survey data also noted that these factors have an influencing behavior on child participation in different child activity options (Okpukpara and Odurukwe, 2003). Family dynamics and poor public education systems are also cited as major contributors to child labour (Brown, 2006). Togunde and Carter (2008) showed that children whose parents have higher socio-economic status are more likely to own business rather than to assist parents, and these children work fewer hours as compared to the children who belong to lower socio-economic status. Other factors identified as sustaining child labour especially street hawking in some parts of Nigeria as noted by Dantiye and Haruna (2004) include the fact that hawking is seen as a means by which young girls attract suitors and a means for raising money for buying items in preparation for marriage for the young hawkers. Also, ILO (1998) submitted that $40 \%$ of street children are employed as sex workers, drug peddlers, car washers and bus conductors for economic ends. ILO, (2007) survey of child labour in Nigeria identified eight causative factors. These are cultural influence, economic problems, national debt, low education, unemployment/inability to cope, street life and single parents' families, with the last three factors exacerbating poverty.

In the same vain. Ugochukwu et al, (2012) studies unanimously agreed that poverty is the main cause, although not the only causes of child labour. They went on to emphasize that despite extreme poverty, parents might not want to send their children for full time job. However, if the parents are hit by temporary economic crisis, then the additional income from child employment could be essential for survival.

\subsection{Empirical Literature Review}

Ukoha, Nwaru and Emea (2007),studied the determinants of child labour in Nigeria using cross sectional data derived from a random sample of 60 rural children from farm households. Means and probit regression model were used in data analysis. They find that educational level of the child, household size and income and educational level of the child's household head were statistically significant determinants of child labour use in agricultural activities. It is recommended that household income enhancement policies should be formulated as components of strategies for effective child labour reduction efforts.

Nwaru et al (2011) examined the determinants of child labour among rural and urban farm households in Abia state of Nigeria. Cross sectional data gotten from a random sample of 60 farm households were analysed using the probit regression model. The result showed that age of the child, sex of the child, education of household, finances were significant determinants of child labour participation. It recommended economic policies capable of enhancing the opportunities of household for increased income should be put in place.

Ndem, Baghebo and Otu (2012) investigated the existence of child labour, causes ,constraints and economic implication in Calabar ,Cross river state, Nigeria. A stratified random sampling method was carried out in 500 respondents through interviews, questionnaire and focused group discussions. Simple percentages and chi-square were used to analyse the data. The study showed a significant relationship between child labour and poverty, unemployment and school dropout. The study recommended that government should come up with legislations that will tackle the problem of poverty and unemployment in Nigeria.

Amao, Oni, Yusuf and Omonona ( 2016 ) examined the determinants of child labour and schooling in rural north eastern Nigeria. Primary data were collected from 969 children. Data were analysed using descriptive statistics and multinomial logit regression. The result showed that a unit increase in the age of children reduced the probability of combining school with work and the determinants of child labour were age, sex, poverty, status of households. It recommended that households should be encouraged to allow all children aged 5-14 year to participate in schooling.

Adeoye et al( 2017) examined the dimension and causes of child labour among rural farm households in Nigeria. A multi-stage sampling technique was used to select 128 rural households for the survey, a total of 352 children were interviewed. Structured questionnaire was used to collect data. Measures of central tendency dispersion and Tobit regression model were used as analytical technique. The study finds age and educational level of household head, distance of home to school, sex of child and proximity of households to major roads as major factors that causes child farm use. It recommended that rural infrastructure development and households economic empowerment initiatives are central to child labour reduction strategies.

\section{METHODS AND PROCEDURES}


This study is basically a survey research which gathered data through interview schedule. This study was restricted to informal sectors in Onitsha, Anambra state, Nigeria because Onitsha is a commercial city with industries and market. Because of its nature, children engage in labour activities in markets and public places to earn income.

\subsection{Design of the Study}

This study used a descriptive survey research design. A descriptive study entails the systematic collection and presentation of data to give a clear picture of a particular situation (Eboh, 2009). It is also a method of collecting information by interviewing or administering of questionnaire to a sample element. The Interview schedule was used as an instrument for this study. The interview schedule was used to elicit information from the child labourers on their point of duty through personal interview. The researcher used structured questions which are in a two- way questions. The schedule was ticked by the researcher and also was recorded on the tape. Igbo language was used for the interview on children because most of the child labourers do not speak English language. The interview lasted for one week and was conducted between 9.00 am to $4.30 \mathrm{pm}$

\subsection{Population, Sampling Technique and Sampling Procedure}

A population is made up of all conceivable elements, subjects or observations relating to a particular phenomenon of interest to the researcher (Asika, 1991). Population is therefore the totality of any group, object or persons which has some unique attributes. Child labourers make up the population of this study which can be seen in communities, streets, markets etc. The total number of child labourers are not known, so the researcher made use of non-probability sampling technique. The researcher made use of non probability sampling because the study does not involve randomness and the population of the study was unknown. (Asika, 1991) In other words, the researcher has to imagine the population element. The researcher made use of quota sampling and purposive sampling technique. Quota sampling and purposive sampling techniques were considered appropriate because the population elements are not deliberately given equal chance of being selected and also data was collected where the respondents are available. Based on the researchers' knowledge about the area of study, the researcher selects his sample for the study. Using the quota sampling, the population is segmented into mutually exclusive sub- groups and the researcher selected the units from each segment based on a specified proportion. We have 24 layouts in Onitsha according to the National Population Authority. For the purpose of this study, some of these areas were grouped into 4, thereby having four sub groups. From the sub groups, a proportionate number of 400 interview schedule was used to elicit information on the child labourers from 5 to 17 years through personal interview until the whole instrument finished.

\section{Data Analysis}

To study the determinants of child labour in informal sector in Onitsha metropolis, a total of 400 child labourers were interviewed using interview schedule. The analyses that follow are based on this. We begin the discussion by presenting the descriptive statistics of the research survey based on the responses elicited from the sampled population. This is done using tables (cross tabulation) showing the frequency distributions and simple percentage rating of the participants and charts (bar and pie charts).

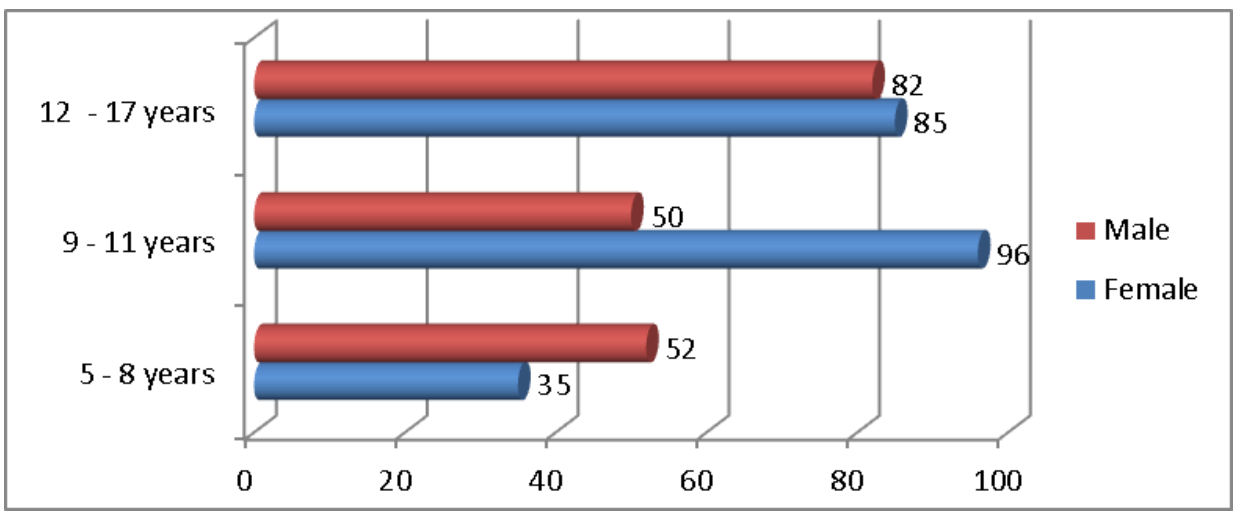

Figure 4.1: Distribution of respondent by age and gender

Source: Researchers' Field survey, 2017. 
Figure 4.1 shows the age and sex distribution of the sampled population. 87 respondents are between the age brackets 5- 8 years, out of this number, 35 are female while 52 are male. Out of 146 respondents who fall within the age brackets $9-11$ years, 50 are male while 96 are female. Further, the result indicates that 167 respondents are between 12 - 17 years, out of this figure, there are 82 male and 85 female. Evidently, there are more female child labourers (about 58\%) than male child labourers (about 42\%) in the Onitsha metropolis and most of the child labourers $(78 \%)$ are between the age brackets $9-17$ years.

Table 4.1: Distribution of respondents on the type and age of working

\begin{tabular}{|c|c|c|c|c|}
\hline & At what age di & art working? & & \\
\hline What type of & & than 12 years & More tl & rs total \\
\hline work do you & Apprentice & 80 & 0 & 80 \\
\hline do? & Sales services & 240 & 12 & 252 \\
\hline & Bus conductor & 0 & 16 & 16 \\
\hline & Artisan & 0 & 52 & 52 \\
\hline & Total & 320 & 80 & 400 \\
\hline
\end{tabular}

Table 4.1 shows the interaction of the type of work engaged by the respondents and the age they started working. The table shows that out of 320 respondents, who started working at less than 12 years of age, 80 are apprentice and 240 are into sales services. On the other hand, from 80 respondents who started working at more than 12 years of age, 12 respondents are into sales services, 16 are bus conductors and 52 are artisans. In the final analysis, it is clear that most of the child labourers (about $63 \%$ of them) are into sales service.

Table 4.2: Distribution of Respondents by the family size

\begin{tabular}{lcc}
\hline \multicolumn{1}{c}{ Family size } & Frequency & Percent $(\%$ \\
\hline Less than 4 & 60 & 30 \\
$5-9$ children & 138 & 69 \\
10 and above & 2 & 1 \\
Total & 200 & 100 \\
\hline
\end{tabular}

Source: Researchers' Field Survey, 2017.

Table 4.2 shows the family size of the respondents have. 60 respondents, representing about $30 \%$ claim that their parents have between $1-4$ children. While 138 respondents (about 69\%) of them claim that they have between 5 - 9 children, 2 respondents (1\%) said they have about 10 children and above.

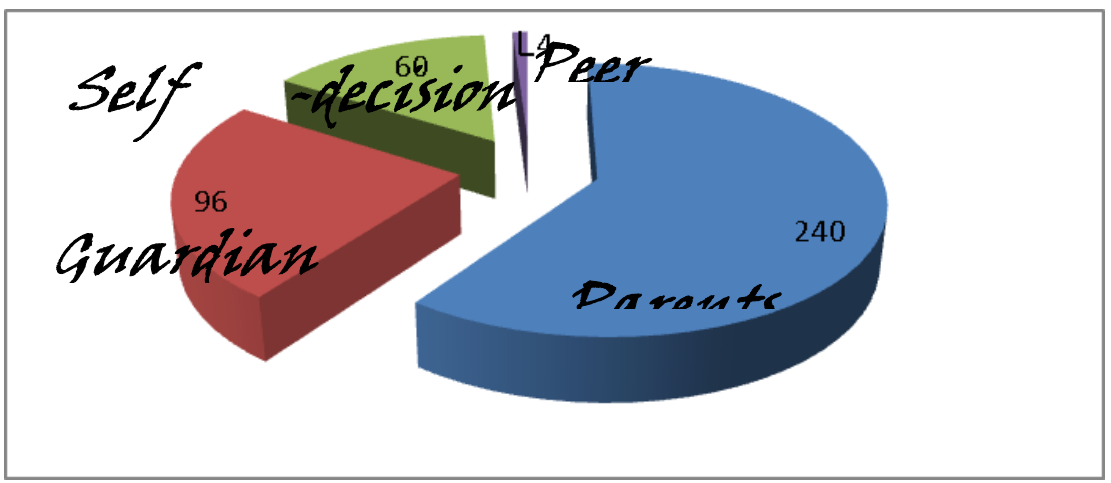

Figure 4.2: Respondents view on who sent them to work Source: Researchers' Field Survey, 2017. 
Figure 4.2 shows that 240 children are being sent to work by their parents which represents about $60 \%$ of the population, those sent to work by their Guardian are 96 which represent about $24 \%, 60$ of the children decided to work on their own which is about $15 \%$ and 4 children went into work based on peer influence which represent about $4 \%$

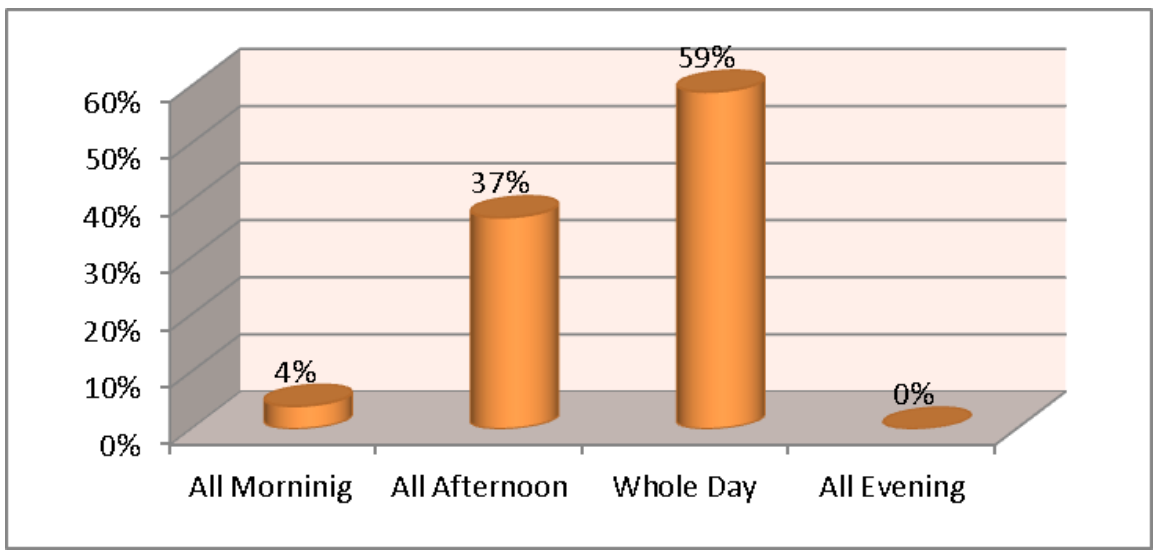

Figure 4.3. Respondents' view on hours spent at work

Source: Researchers' Field Survey, 2017.

Figure 4.3 shows the number of hours the children spends at work, 16 number of children works in the morning which is about $4 \%$ of the population , 148 of them works in the afternoon which represents about $37 \%$ of the population,236 children spends the whole day in working which represents about $59 \%$ while non-responded to evening .

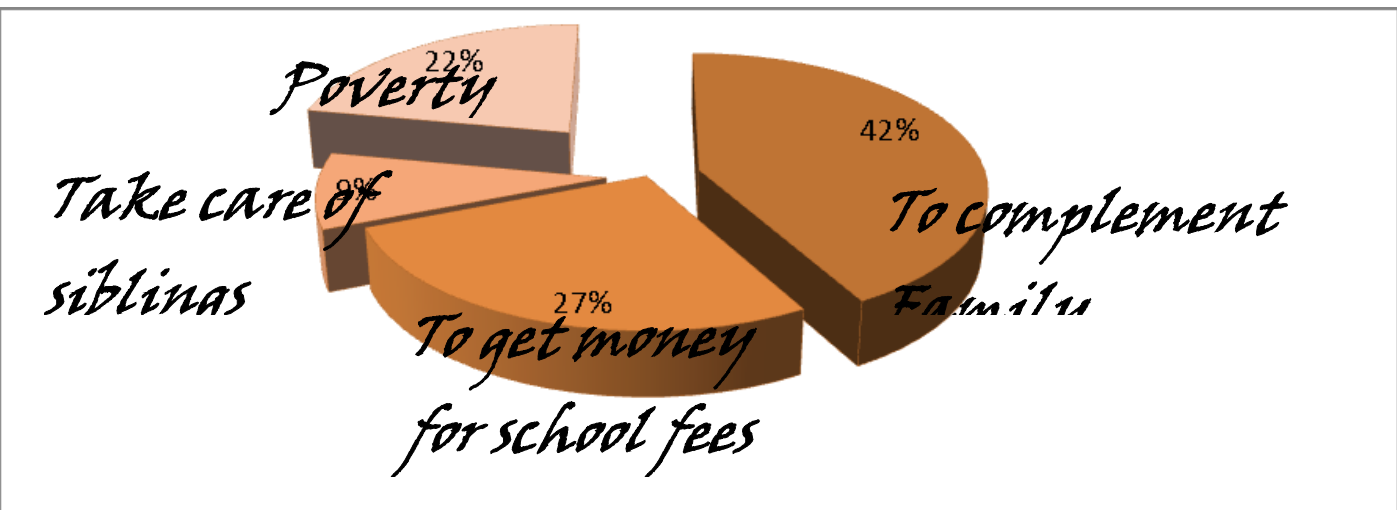

Figure 4.4: Respondents view on reason for entering into work

Source: Researchers' Field survey, 2017.

Figure 4.4 shows the reason why children enter into work.168 children work in order to complement their family income which represent about $42 \%$ of the population, 108 children worked in order to get money for school fees which represent about $27 \%$ of the population, 36 children works in order to take care of sibling which represent about $9 \%$ and 88 of the children worked because of poverty which represents about $22 \%$. 


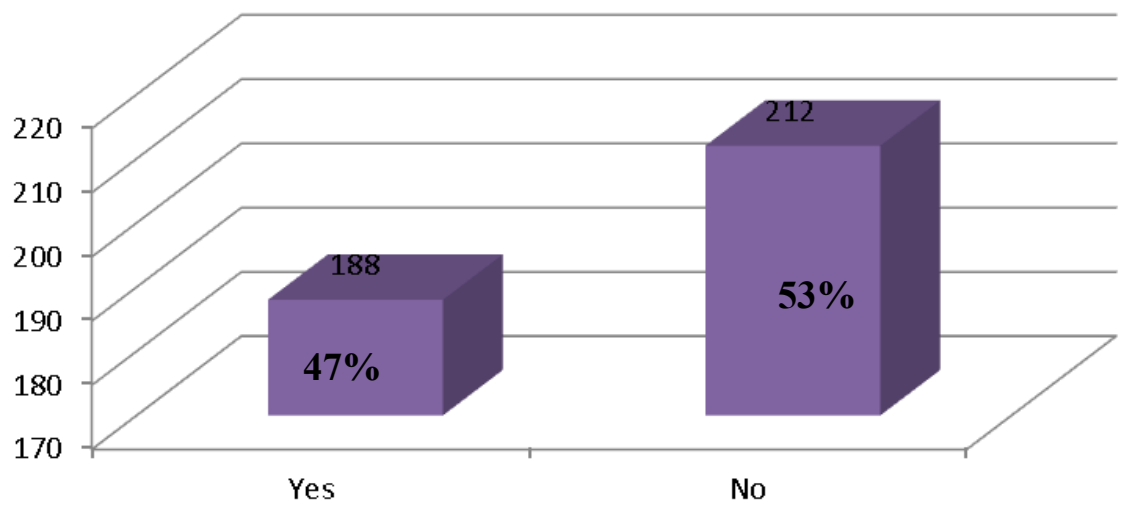

Figure 4.5: Respondents view on enrollment in school

Source: Researchers' field survey, 2017.

Figure 4.5 shows the number of children who are in school and those who are not. 188 children responded being in school which represents about $47 \%$ of the population while 212 children are not in school which represents about $53 \%$ of the population.

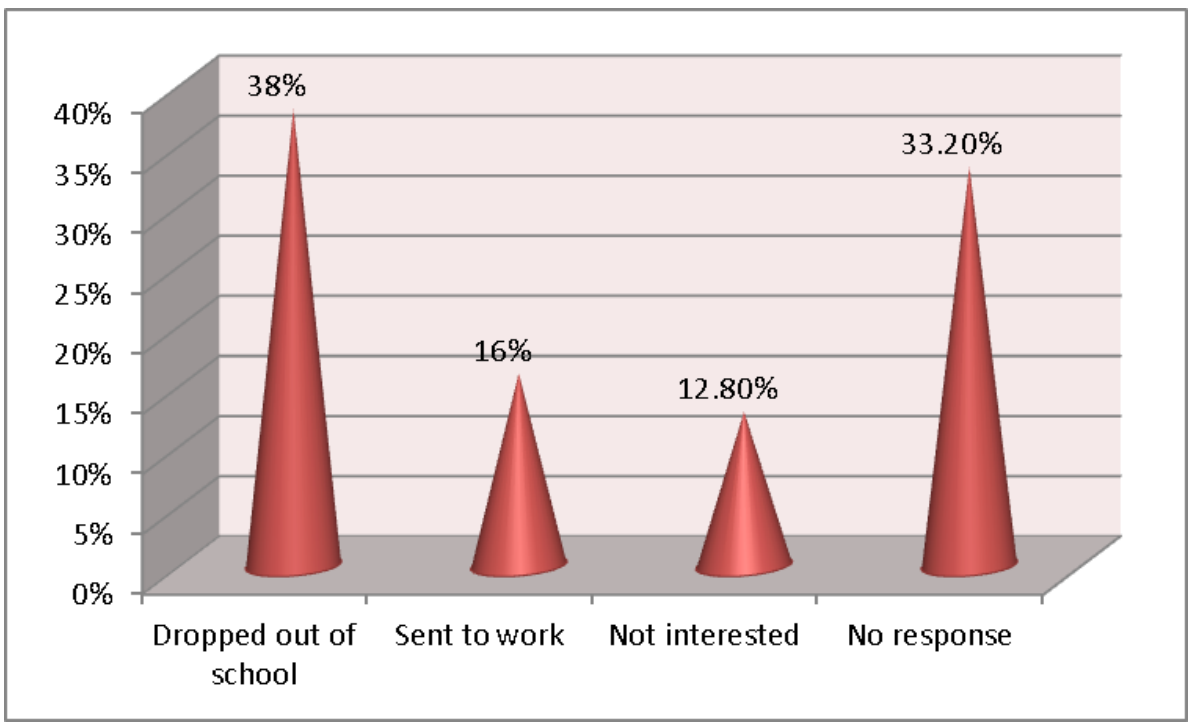

Figure 4.6: Respondents' view on reason for not being enrolled in school

Source: Researchers' Field survey, 2017.

Figure 4.6. shows the reason why some children are not in school, 38\%of the children dropped out of school, while about $16 \%$ were sent to work, about $12.80 \%$ are not interested in education and $33.2 \%$ represents those who are in school. 
Table 4.3: Distribution of respondents on the type of school

\begin{tabular}{|l|l|l|}
\hline Case & Frequency & Percent (\%) \\
\hline Government & 116 & 29 \\
Private & 32 & 8 \\
Mission & nil & 0 \\
No response & 252 & 63 \\
Total & 400 & 100 \\
\hline
\end{tabular}

Source: Researchers' Field survey, 2017.

Table 4.3 shows the type of school they are enrolled in.116 children are in Government school which is about $29 \%, 32$ of them are in private school which represent $8 \%$ while none of the children attends mission school. Most of the children interviewed are from Government school.

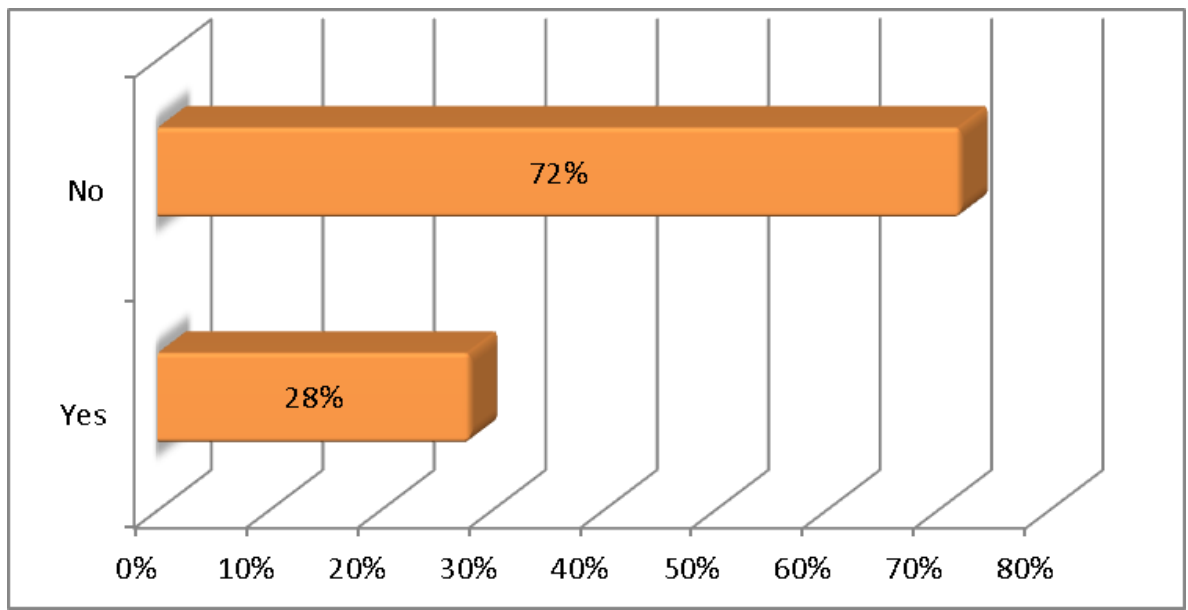

Figure 4.7: Respondents view on academic performance

Source: Researchers' Field Survey, 2017

Figure 4.7 shows the rate at which the students are affected academically. $72 \%$ of the children are not affected in their academic performance while $28 \%$ of the children are affected in academic performance. In the final analysis, it means that most of the children are not affected in their academic performance.

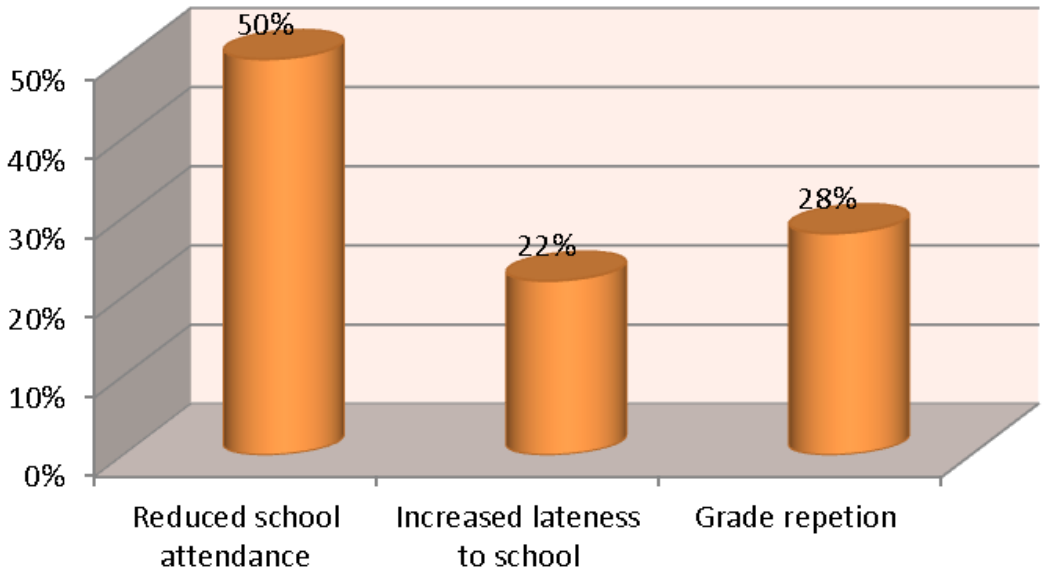

.Figure 4.8: Respondents view on how work affects their academic performance Source: Researchers' Field survey, 2017 
Figure 4.8 shows how the child's academic performance is affected. $50 \%$ are affected by reducing their attendance in school while $22 \%$ are affected through increase in their lateness to school and $28 \%$ were affected through grade repetition. Most of the children are affected through reduction in school attendance.

Table 4.4: Distribution of respondents on Stress or depression being experienced Source: Researchers' Field survey, 2016.

\begin{tabular}{|c|c|c|c|c|c|}
\hline & & has this wor & cted your mer & tal well-being & \\
\hline Does this & & augh at me & low in spirit & No response & Total \\
\hline & Yes & 140 & 4 & 0 & 144 \\
\hline you & No & 0 & 0 & 256 & 256 \\
\hline mentally? & No response & nil & 0 & 0 & 0 \\
\hline & Total & 140 & 4 & 256 & 400 \\
\hline
\end{tabular}

Table 4.4 shows how the children are affected by stress or depression.144 children responded being affected by stress/depression while 256 children were not affected by any stress. Out of the 144 children that are stressed or depressed in one form or the other, 140 of them admitted that their mates laugh at them in the public while 4 of them feel low in spirit.

Table 4.5. Respondent's view on sickness exposed

\begin{tabular}{|l|l|l|}
\hline Case & Frequency & Percentage\% \\
\hline Yes & 344 & 86 \\
\hline No & 56 & 14 \\
\hline Total & 400 & 100 \\
\hline
\end{tabular}

Source: Researchers' field survey, 2016

Table 4.5 shows the number of children who are exposed to one sickness or the other as a result of their work. 340 children responded having one sickness or the other which represent about $86 \%$ of the population while 60 of the children are not exposed to any sickness which represents about $14 \%$ of the population.

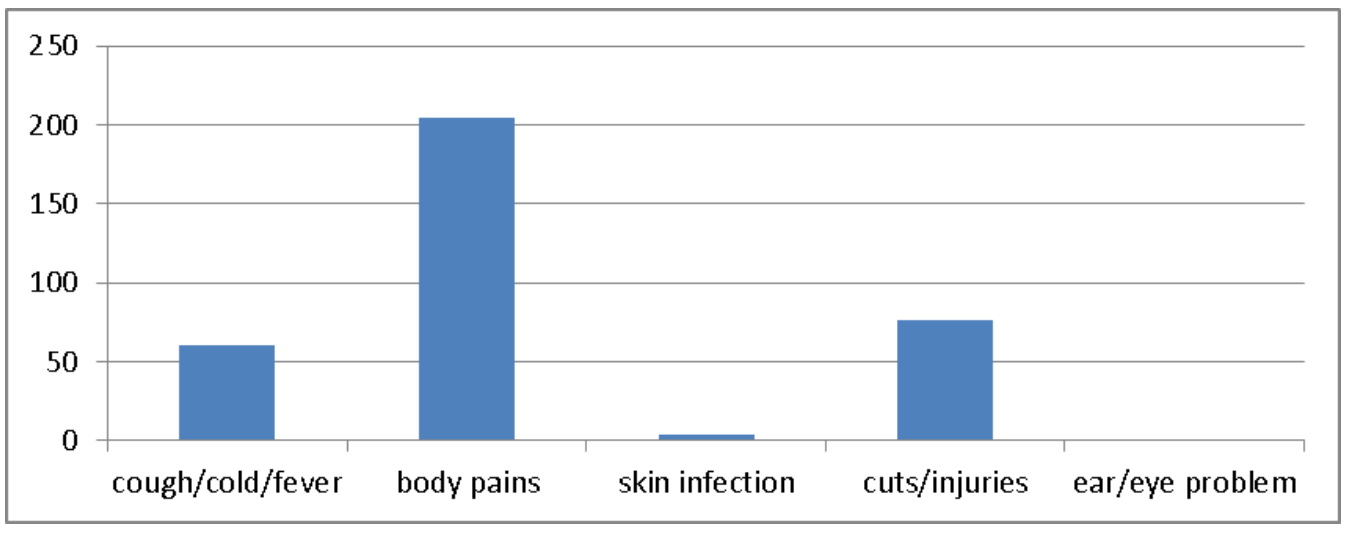

Figure 4.9 . Respondents view on nature of sickness

Source: Researchers' Field Survey, 2017.

Figure 4.9 shows how children are affected because of their work. 60 of the children are exposed to cough/cold/fever, 204 of them have body pains, 4 of them have skin infection, 76 of them have cuts/injuries while none of them has ear or eye problem. It was observed that most of the children have body pains. 
Table 4.6: Respondents view on dangers experienced at work

\begin{tabular}{lcc}
\hline Case & Frequency & Percent (\%) \\
\hline Yes & 208 & 52 \\
No & 192 & 48 \\
Total & 400 & 100
\end{tabular}

Source: Researchers' field Survey, 2017

Table 4.6 shows the danger the children encounters.208 of the children responded positive to danger which represents about $52 \%$ of the population while 192 of them responded negative to any danger which represents about $48 \%$.

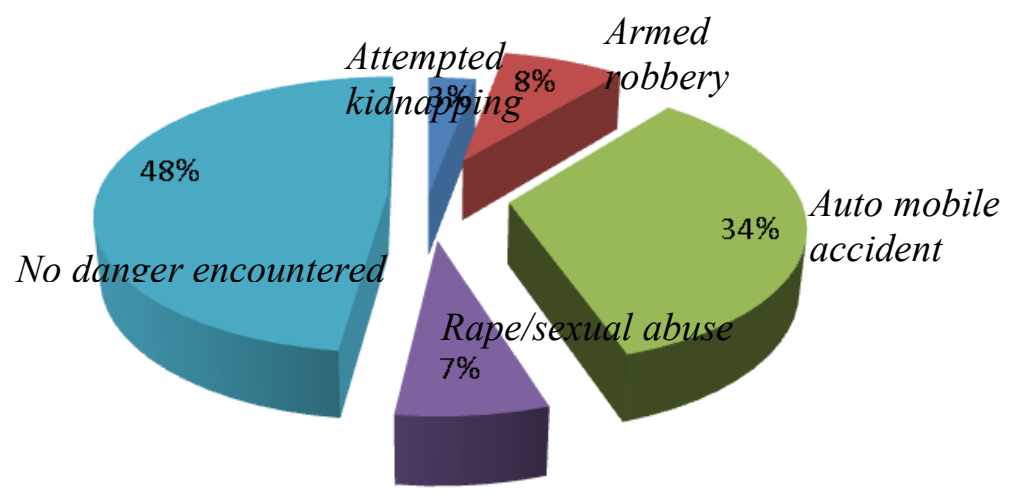

Figure 4.10: Respondents view on type of danger encountered

Source: Researchers' Field survey, 2017.

Figure 4.10 shows the type of danger the children encountered.3\% of the children encountered being kidnapped, $8 \%$ encounter armed robbery attack, $7 \%$ encounter rape/sexual abuse ,34\% encounter automobile accident while $48 \%$ did not encounter any danger. Most the respondents experience automobile accident.

Table 4.7. Respondents view on awareness

\begin{tabular}{|l|l|l|}
\hline & Frequency & Percentage (\%) \\
\hline Yes & 152 & 38 \\
No & 248 & 62 \\
Total & 400 & 100 \\
& & \\
\hline
\end{tabular}

Source: Researchers Field Survey, 2017

Table 4.7 shows that 152 children are aware of what child labour is which represents about $38 \%$ of the population while 248 of them are not aware of what child labour is which represent about $62 \%$. 


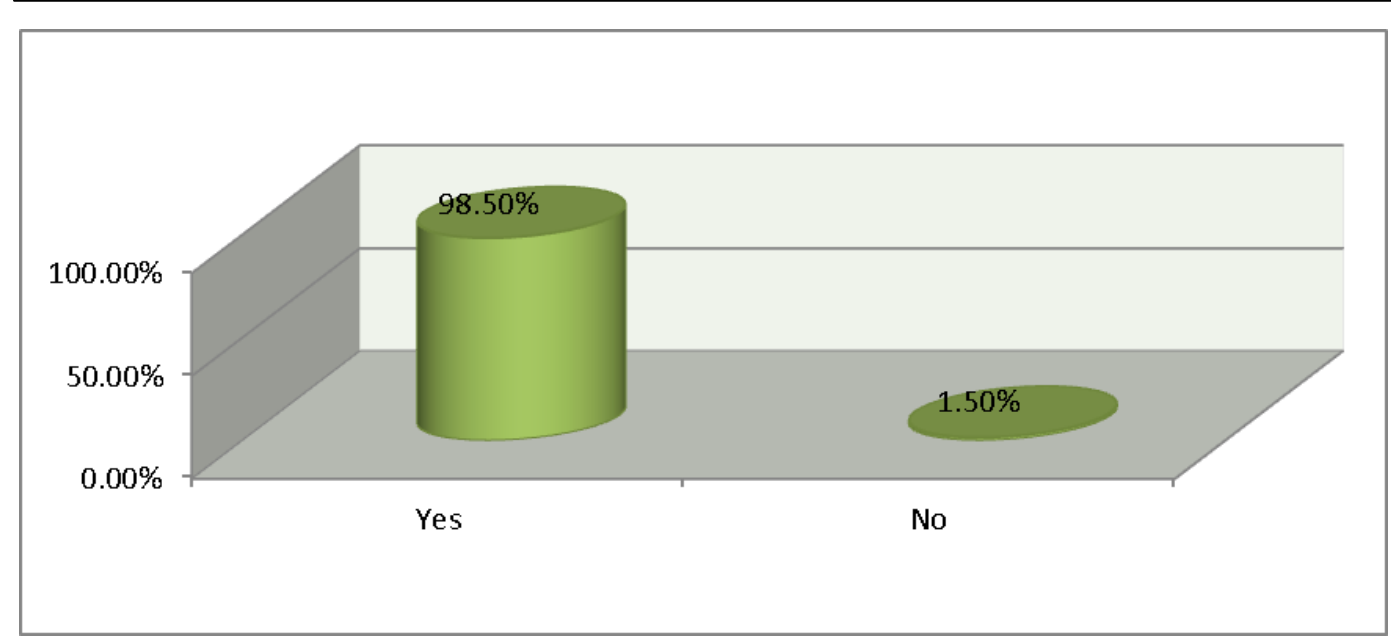

Figure 4.11: Respondents view on whether child labour should be stopped

Source: Researchers' Field survey, 2017.

Figure 4.11 shows that $98.5 \%$ of the children wished that child labour should be stopped while $1.5 \%$ wished that child labour should not be stopped.

\subsection{Discussion of Findings}

From the research findings, it was observed that most of the families or households have between 5-9 children and because of the increase in the number of children, the solution lies in sending them to work or learn trade in order to reduce their financial obligations. Some of the child labourers interviewed are between 9-17 years and are mostly female. It was observed that some of the parents did not pass through formal education in the western sense. Most of them have either primary or secondary education. It was also observed that some of the children interviewed are not aware of what child labour entails. Most people in Onitsha metropolis engage their children in sales services and direct selling of petty trade in which they are being encouraged or sent to work mostly by their parents. This is to say that parents are the major determinant of child labour supply in Onitsha metropolis. Most of the children claim that the reason for entering into work is to increase their parents income which helps their parents to overcome economic hard times (recession).

About $45 \%$ of the child labourers are engaged in sales and direct petty trade such as hawking of satchet water (pure water), oranges, vegetables to complement their parents' income and to pay their school fees. Most of the children are also found not to be enrolled in school and those who were enrolled eventually dropped out of school because of the financial status of their parents and ignorance of the benefits of child education. On the other hand, some of the children who engage in hawking and were also in school claim that it never affected their academic performance while others were affected through reduction in school attendance. It was also observed from the descriptive analysis that most of them do not experience depression but did experience stress in their daily life. Some of the child labourers are being embarrassed in the public by the colleagues who were in school.

The research observed that child labour exposed children engaged in it to different sickness such as cold, body pain, and headache. It also exposed them to different dangers like mobile accident, armed robbery attack and sexual abuse. The baseline of the analysis shows that the prominent factors that cause child labour are parents' ignorance, illiteracy, low income, family size, low level of awareness and high cost of living.

\section{Conclusion.}

This study examined child labour and its determinants in Nigeria with specific focus in informal sector of Onitsha Metropolis. Primary data generated from a sample of 400 children who are on duty were used. Results indicated that Parents are the major determinant of child labour supply in Onitsha and that the factors that causes child labour are illiteracy, Parents ignorance, low level of awareness, high cost of living and low income. Based on the research findings, the following recommendations are made; It is imperative that both government and non-governmental organization be set up to critically assess, design and monitor programmes that will help to 
empower parents financially in order to make them have the choice of sending their children to school instead of work. Government should also find a way to reduce the financial pressure often times mounted on parents which force their children to work to augment their income.

\section{REFERENCES}

Adeoye S.O, Agbonlahor M.U, Ashaolu O.F \& Ugalahi U.B. (2017). Analysis of child labour dimensions and causes in rural farm household of Ogun state, Nigeria. African Journal of food, Agriculture, Nutrition and Development.17(3) .

Amao, I.O, Oni, O.A, Yusuf S.A and Omonona B.T (2016). Determinants of child labour and schooling in Rural Northeastern Nigeria. Journal of Rural Economics and Development .19(1),1-45.

Asika, N.M. (1991). Research methodology in social science. Lagos: Estorise Publisher Nigeria Limited .

Basu, K. (1998). Child labour: Cause, Consequence, and cure, with Remarks on International labour standards. Policy Research Working Paper 2027. Washington, D.C., The World Bank.

Basu, K.(1999). Child labour: Causes, consequence and cure with remarks in international labour standard. Journal of Economic Association.37(3),1083-1119.

Brown, .D. (2006). Consumer product labels, child labor, and educational attainment. Contributions to Economic

Analysis and Policy, 5(1).

Dantiye, .S., \& Haruna, .A. (2004, April 30). Hawking, child abuse or economic supplements for parents. Daily trust newspaper, p. 26

Ebo, E.C. (2009). Social and economic research, principles and methods. Enugu: African Institute for Applied Economics.

Grootaert, C. (1995). Child labour: An economic perspective. International Labour Review 134 (2), 187-203.

ILO (1998). International Labour Conference on Child Labour: Targeting the Intolerable. International Labour Organization, Geneva.

ILO (2007). Children in hazardous work: what we know and what we need to do. International labour office. Geneva.

Isamah, A.N. and Okunola, R.A. (2002). Family Life under Economic Adjustment: The Rise of Child Bread winners. In Guyer J.I., Denzer L. and Agbaje A.A. Money Struggles and City Life: Devaluation in Ibadan and Other Urban Centre in Southern Nigeria, 1986-1996. Portsmouth, NH: Heinemann.

International Programme on the Elimination of Child Labor IPEC (2002). Investing in Ever Child: An Economic Study of the Costs and Benefits of Eliminating Child Labour.

Ndem B.E, Baghebo M. \& Otu C.A,(2012).Child labour in Nigeria and its economic implications: A case study of Calabar. Research on humanities and social sciences 2(9)149-159.

Nwaru J.C., Egbulefu I., Odoemelam L.E., (2011).Determinants of child labour among Urban and rural farm households in Abia state, Nigeria. European journal of social science 23(2) 311.

Obikeze, D. S.(1986). Agricultural Child Labour in Nigeria; A Case Study of Anambra State in Child Labour in Africa. Proceeding of the First International Workshop on Child Abuse in Africa, Enugu .

Okpukpara, B.C. and Odurukwe N. (2003). Incidence and Determinants of Child Labour in Nigeria: Implication for Poverty Alleviation. Journal of Economic Policy. 10(2),2003 
Oloko, S.B.A (2004). Child Labour in Nigeria: Continuities and Transformation. Inaugural Lecture Delivered at the University of Lagos: Lagos University Press, Lagos.

Ozoji, R.(2017, September, 7). Anambra goes tough on child labour. The Oracle Newspaper. Retrieved from www.oraclenews.ng

Tade, O. (2010). Household Demand and Child Trafficking for Domestic Use in Ibadan, Nigeria. A Ph.D. postfield Seminar presented at the Department of Sociology, University of Ibadan, Nigeria.

Taiwo, I. (2010,March 23). Toyota Bus Stop: Gridlock without end. The Guardian Newspaper.

Togunde, D. and Carter A. (2008). Socio-economic causes of child labor in urban Nigeria. Journal of Children \& Poverty, 12(1), 89-105.

Ugochukwu, E.F., Okeke, K.N., Onubogu, C.U. and Edokwe, E.S. (2012). Socio-Demographic Characteristics of child Street Vendors in Nnewi, Nigeria. Niger J Paed, 39 (4), 174-178

Ukoha O.O, Nwaru J.C \& Emea M. (2007).Determinants of child labour in crop production in Nigeria: A case study of Abia State. Pakistan journal of social sciences 4(3) 380-384

UNICEF (2008). Child Protection from Violence, Exploitation and Abuse: To Every Child Health, Education, Equality, Protection. Balaguer: UNICEF Centre.

\section{Appendix : $\quad$ Interview schedule}

\section{Section A-Bio-data of respondent}

1. How old are you? (a) $5-8 \square$ (b) 9-11 $\square$ (c) $12-17$

2. What is your gender? (a) Male (b) Female

\section{Section B}

3. What type of work do you engage in?
(a) Apprentice
(b) sales service
(c) bus conductor
(d) Artisan $\square$

(e) Others specify

4. At what age did you start working? a) less than 12 years 5. Who sent you to work?
(a) Parents
(b) Guardian
(c) Self-decision
(d) Peer influence

6. How long do you spend at work ?
(a) All Morning
(b) all afternoon
(c) Whole day
d) all evening

7. Why did you enter into work?

(b) Get money for school fees

(a) To complement family income

8. Are you currently in school? (a) Yes $\square$ (b) No $\square$ (c) Take care of sibling

(d) Poverty

9. If no to ques 8, why? (a) Dropped out of school $\square$ (b) Sent to work $\square$ (c)School is expensive $\square$ (d) Not interested 
10. If yes to ques.8, what type of school? a) Government

b) Mission

c) Private

11. Does this work affect your academic performance? a) Yes

$\square$ b) No $\square$
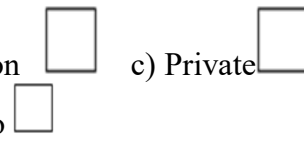

12.If yes, to ques.11, how has that affected your academic perfomance?

(a)Increased lateness to school $L$ (b)Reduced school attendance $\square$ (c)Grade repetition $\square$

(d) lowered class performance $ـ$

13. Have you experienced any stress or depression because of your work? (a)Yes $\square$ ( b) No

14. How has this work affected your mental well-being? (a) Peers laugh at me $\_$(b) low in spirit

Mental disorder due to depression $\square$ (d) separation from friends /family relations $\square$

15. Are you exposed to any sickness because of your work? (a) Yes $\square$ (b) No $\square$

16. If yes, what was the nature of the sickness? (a) cough/cold/fever $\square$ (b) body pain $\square$ (c)skin infection $\square$ (d)cuts/injuries $\square \quad$ (e) Ear/Eye problem $\square$ (f) stunted growth $\square$

17. Have You ever experienced any danger in your work? (a) Yes $\square$ (b) No $\square$

18. if yes, what kind of danger (a) Armed robbery $\square$ (b)automobile accident $\square$ (c) Rape/sexual abuse $\square$ (d) Attempted kidnapping

19. Are you aware of what child labour is? (a) Yes

(b) NoL

20. Do you wish child labour should be stopped ? (a) Yes $\square$ (b) No $\square$ 